\title{
EFFECTS OF CAFFEINE AND ETHANOLIC EXTRACT OF KOLANUT ON GLUCOSE UPTAKE IN THE CANINE HINDLIMB AT REST AND DURING CONTRACTION
}

\author{
H. M. SALAHDEEN AND A. R. A. ALADA
}

Department of Physiology, College of Medicine, University of Ibadan, Ibadan, Oyo State, Nigeria

E-mail:dralada@yahoo.com

\begin{abstract}
Summary: The study investigated the effects of caffeine and ethanolic extract of kolanut (EEK) on glucose uptake in the canine hindlimb at rest and during contraction. Thirty male anaesthetized Mongrel dogs (11 - $13 \mathrm{~kg}$ ) were divided into six groups (5dogs/group). Caffeine $(6 \mathrm{mg} / \mathrm{kg})$, EEK $(5 \mathrm{mg} / \mathrm{kg})$, or normal saline (control) was administered intravenously to each group at rest. Arterial and venous blood samples were collected at $0,5,10,15,20,25,30,45,60,75$ and 90 minutes after drug administration. Blood glucose was measured by glucose oxidase method. Arterio-venous (A-V) glucose difference was calculated and venous blood flow (VBF) was measured during the sampling period. Hindlimb Glucose Uptake (HGU) was calculated as the product of $(\mathrm{A}-\mathrm{V})$ glucose and blood flow. After sampling at rest, the experiments were repeated with the right femoral nerve stimulated using electrical stimulator at $5 \mathrm{~Hz}$. At rest, $(\mathrm{A}-\mathrm{V})$ glucose increased significantly $(\mathrm{P}<0.05)$ from $4.2 \pm 0.2 \mathrm{mg} / \mathrm{dl}$ to $29.8 \pm 8.6$, and $24.4 \pm 2.6$ for caffeine and EEK respectively. VBF decreased to $2.0 \pm 0.9$ and $6.0 \pm 0.6 \mathrm{ml} / \mathrm{min}$ for caffeine and EEK respectively. However, HGU significantly increased from $34.8 \pm 0.1 \mathrm{mg} / \mathrm{min}$ to $74.5 \pm 3.2 \mathrm{mg} / \mathrm{min}$ and $175.8 \pm 3.4 \mathrm{mg} / \mathrm{min}$ for caffeine and EEK, respectively. Contraction of the hindlimb muscle alone significantly increased the (A-V) glucose (68\%), VBF (26\%) and HGU (120\%) when compared with the control. During contraction, (A-V) glucose increased from $4.3 \pm 1.5 \mathrm{mg} / \mathrm{dl}$ to $35.6 \pm 3.0 \mathrm{mg} / \mathrm{dl}$, and $27.0 \pm 2.2 \mathrm{mg} / \mathrm{dl}$ for caffeine and EEK respectively. VBF also increased from $8.4 \pm 0.3 \mathrm{ml} / \mathrm{min}$ to $12.8 \pm 0.3 \mathrm{ml} / \mathrm{min}$ for EEK. Although, contraction improves $\mathrm{VBF}$ $(7.3 \pm 0.5 \mathrm{ml} / \mathrm{min})$ to the hindlimb in response to caffeine, the value was significantly $(\mathrm{P}<0.05)$ lower than that of control $(8.4 \pm 0.5 \mathrm{ml} / \mathrm{min})$. Contraction also significantly increased HGU from $35.8 \pm 3.6 \mathrm{mg} / \mathrm{min}$ to $249.0 \pm 3.3$ and $286.72 \pm 2.0 \mathrm{mg} / \mathrm{min}$ for caffeine and EEK, respectively. The results showed that caffeine and EEK significantly increased HGU and that these effects are due to the increases in glucose extraction ((AV) glucose) caused by caffeine and EEK.
\end{abstract}

Key words: Caffeine, kolanut, dog, glucose uptake, hindlimb

\section{Introduction}

Administration of caffeine has been demonstrated to cause a transient impairment of glucose tolerance in able-bodied human (Graham et al, 2001; Petrie et al, 2004; Robinson et al, 2004; Thong and Graham 2002). During an oral glucose tolerance test (OGTT) caffeine ingestion results in elevated insulin and C-peptide responses without a subsequent lowering of the glucose response (Graham et al, 2001; Thong and Graham 2002), suggesting a caffeineinduced impediment to the action of insulin. This impediment in the action of insulin is further demonstrated by studies employing the euglycaemic-hyperinsulinemic clamp technique that reported a $15-25 \%$ decrease in whole body insulin-mediated glucose disposal following caffeine ingestion (Thong and Graham 2002; Keijzers et al, 2002; Thong et al., 2002). Furthermore, Thong et al, (2002) demonstrated a $50 \%$ decrease in skeletal muscle (leg) glucose uptake, which is the predominant tissue responsible for whole body glucose disposal in humans.
The mechanism by which caffeine decreases glucose tolerance and/or glucose disposal remains undetermined. Although caffeine is a known adenosine receptor antagonist (Biaggioni et al, 1991; Smits et al, 1987), it remains unclear as to whether or not adenosine contributes significantly to insulin-mediated glucose uptake with skeletal muscle. Within adipose tissue, adenosine has been consistently reported to enhance insulin-mediated glucose uptake (Christ et al, 1998; Hellsten, et al, 1998); however, the results obtained for skeletal muscle have been conflicting. Studies conducted on rodent muscle have demonstrated increases (Espinal et al, 1983; Leighton et al, 1988), decreases (Han et al, 1998) and no change (Vergauwen et al, 1994) in insulin-mediated glucose uptake following the administration of an adenosine receptor antagonist. In humans, the infusion of the adenosine reuptake inhibitor dipyridamole failed to show an enhancement of whole body insulin-mediated glucose disposal during a euglycaemic-hyperinsulinemic clamp, suggesting 
H. M. Salahdeen and A. R. A. Alada

that adenosine may not contribute significantly to insulin action in humans (Graham et al, 2001).

Again, until recently, it was believed that the small, albeit significant, elevation in epinephrine concentration observed following caffeine ingestion was most likely responsible for the impairment in glucose tolerance (Thong and Graham 2002; Battram et al, 2005). However, although epinephrine is a potent antagonist of insulin-mediated glucose disposal (Deibert and De Fronzo 1980; Bessey et al, 1983, Baron et al, 1987), the infusion of epinephrine in concentrations similar to those observed following caffeine ingestion did not significantly impede insulin-mediated glucose disposal (Battram et al, 2005).

Most of the literature on the relationship between caffeine and glucose uptake in skeletal muscle have been limited to humans and rodents with little work done on dogs. However, a recent report by Pencek et al, (2004) showed that infusion of caffeine through the portal vein in conscious dogs caused significant increases in hepatic glucose uptake. There is no information on how the skeletal muscle handles glucose uptake following administration of caffeine in the dog. The present study was therefore designed to study the effect of intravenous administration of caffeine on the glucose uptake by the canine hindlimb. The second part of this study also tried to investigate the effect of kolanut extract on the glucose uptake by the canine hindlimb. Kola nut contains several organic compounds including caffeine. There are reports that suggest that caffeine content of kola nut could be as high as 7\% (Ogutuga, 1975) and is often considered to be the agent responsible for the biological action of kola nut (Chukwu et $a l, 2006)$. The question now asked is: Will kola nut extract produce the same effect as caffeine on the hindlimb glucose uptake?

\section{Materials and methods}

Selection of Kolanut and preparation of ethanolic extract:

Seeds of specie Cola nitida were used in this study. The seeds were purchased from a market in Ibadan, Nigeria and authenticated for identification at the Department of Botany and Microbiology, University of Ibadan where a sample was kept. The seeds were dried under shade for almost two weeks and thereafter reduced to powdered form. One kilogram of the powdered seeds was obtained and exhaustively extracted with ethanol. Powdered kola nut was extracted ( $1 \mathrm{~kg}$ per 2 liters) two times with ethanol and water $(80: 20 \mathrm{~V} / \mathrm{V})$ for $1 \mathrm{~h}$ at room temperature, under magnetic stirring. After filtration, the solvent was evaporated at $40^{\circ} \mathrm{C}$ under vacuum (Rotavapor), and final ethanolic extract lyophilized. The extract solution was prepared as suspension with $4 \mathrm{~g} / 100 \mathrm{ml}$ of saline for the physiological and pharmacological studies.

\section{Toxicity study}

Acute toxicity of the kolanut ethanolic extract was evaluated using male Swiss mice (25-35grams). An initial pilot study was conducted to determine the dose range of the extract to be used for the study. Fifty-five mice were used to determine the $\mathrm{LD}_{50}$. The mice were divided into 11 groups of 5 mice per group. The doses administered were selected after preliminary experiments. The animals were then observed for a period of 72 hours post-treatment for clinical signs of toxicity such as movements, weakness, sleeping and death to determine the $\mathrm{LD}_{50}$.

Experimental procedure:

Male mongrel dogs weighing $11-13 \mathrm{~kg}$ were used for the study. Each animal was fasted for 18-24hr before the start of an experiment. Anaesthesia was induced by i.v injection of sodium pentobarbitone, $30 \mathrm{mg} / \mathrm{kg}$. Light anaesthiesia was maintained with supplemental doses of i.v. sodium pentobarbitone as necessary. The trachea was intubated using endotracheal tube and the animal was allowed to breath room air (temp. $25^{\circ} \mathrm{C}$ ) spontaneously.

The right femoral vein and artery were cannulated. The cannula in the right femoral vein was moved into an extracorporeal position and a non-crushing clamp was applied to its free end. The left femoral vein was cannulated for the administration of drug and left femoral artery was also cannulated and connected to a twoChannel physiographic recorder through pressure transducer model 7070 Gemini (Ugo basil) to monitor blood pressure and heart rate.

The right femoral nerve was isolated and muscular contraction was induced by electrical square pulses of $0.2 \mathrm{~ms}$ duration using electrical student stimulator to the nerve (Brooks Instruments, UK). The output voltage was limited to $2.5,5$ or $10 \mathrm{~Hz}$ for nonpainful muscle contraction for thirty minutes (Hamada et al, 2004). At the end of surgical procedure, sodium heparin 300unit per kg-body weight was administered intravenously to prevent blood clotting. After all surgical procedures were completed, a 60-90 minutes stabilization period 
Caffeine and kolanut extract on canine hindlimb glucose uptake

was observed. The blood flow to the hindlimb was measured by time collection of the blood from the right femoral vein as previously described by (Alada and Oyebola, 1996). Arterial and venous blood samples for glucose estimation were obtained from the cannula placed in the right femoral artery and vein respectively. After stabilization, basal measurements of the femoral venous blood flow, arterial and venous glucose were determined. The experiments were carried out in six groups (with 5dogs per group). In each group, blood samples for basal glucose measurements were obtained and basal blood pressure and blood flow were also monitored.

\section{Group I (Control)}

A bolus injection of normal saline $(0.1 \mathrm{ml} / \mathrm{kg})$ was given through the femoral vein. Blood pressure and hindlimb blood flow measurements were continuously monitored, while the arterial and venous blood samples for glucose estimation were obtained at $5 \mathrm{~min}, 10 \mathrm{~min}, 15 \mathrm{~min}, 20 \mathrm{~min}$, $25 \mathrm{~min}$, 30min, $45 \mathrm{~min}$, 60min, $75 \mathrm{~min}$, and $90 \mathrm{~min}$ post-injection.

Group II (Normal saline and hindlimb muscle contraction)

A bolus injection of normal saline $(0.1 \mathrm{ml} / \mathrm{kg})$ was given through a cannula in the femoral vein during which the femoral nerve was electrically stimulated at $5 \mathrm{~Hz}$ for thirty minutes using student stimulator (Brooks Instruments, UK) to produce contraction of the hindlimb muscles. The procedures for blood pressure recording, blood flow rate measurement, and blood sample collection for glucose estimation from arterial and venous ends during hindlimb muscle contractions were repeated as in group I.

Group III (Caffeine)

A bolus injection of caffeine at a dose of 3,6 or $9 \mathrm{mg} / \mathrm{kg}$, was given i.v to three separate subgroups of dogs, each subgroup containing 5dogs. The procedure for blood pressure recording, blood flow rate measurement, and blood samples collection from the femoral artery and vein were repeated as in group I.

Group IV (Caffeine and hindlimb muscle contraction)

A bolus injection of caffeine at a dose of $(6 \mathrm{mg} / \mathrm{kg})$, was given i.v. through the femoral vein followed by stimulation of femoral nerve to produced hindlimb contraction for thirty minutes. The procedures for blood pressure, and blood flow monitoring, arterial and venous blood sampling were carried out as in group I during the hindlimb contraction and after stimulation of the nerve.

Group V(Kolanut extract)

A bolus injection of kolanut extract in a dose of $2.5 \mathrm{mg} / \mathrm{kg}$ or $5 \mathrm{mg} / \mathrm{kg}$ ), was given i.v. through the femoral vein to two separate subgroups with 5 dogs per subgroup.. The procedure for blood pressure recording, blood flow rate measurement and blood sample collection from femoral artery and vein were repeated as in-group I.

Group VI (Kolanut and hindlimb muscle contraction)

A bolus injection of kolanut extract at a dose of $(5 \mathrm{mg} / \mathrm{kg})$, was given i.v. through the femoral vein followed by stimulation of femoral nerve to produced hindlimb contraction for thirty minutes. The procedures for blood pressure, and blood flow monitoring, arterial and venous blood sampling were carried out as in group I during the hindlimb contraction and after stimulation of the nerve.

\section{Blood glucose measurement}

Blood glucose was determined with one touch basic-plus glucometer. The meter was checked against the standard glucose solution at regular interval to ensure accuracy. Result of blood glucose measurement using glucometer correlates excellently with the results obtained from standard laboratory methods (Ajala et al, 2003; Devreese and Leroux-Roels 1993). Glucose uptake was computed as the product of the (A-V) glucose and blood flow (Alada and Oyabola 1997).

Data were analyzed using Microsoft Excel statistical package. All values given are the mean \pm S.E of the variables measured. Significance was assessed by the analysis of variance (ANOVA) followed by a post hoc Fisher's PLSD test for multiple comparisons. $\mathrm{P}$ values of 0.05 or less were taken as statistically significant.

Table 1: Effect of ethanolic extract of kolanut on acute toxicity in mice

\begin{tabular}{cccc}
\hline & Doses & No of & \\
Groups & $m g / k g$ & Death & Percentage \\
I & 1 & 0 & 0 \\
II & 100 & 0 & 0 \\
III & 1000 & 0 & 0 \\
IV & 2000 & 0 & 0 \\
V & 3000 & 0 & 0 \\
VI & 6000 & 0 & 0 \\
\hline
\end{tabular}


H. M. Salahdeen and A. R. A. Alada

\section{Results}

Acute toxicity tests in mice:

Table 1 shows the acute toxicity results after administration of graded doses of ethanolic extract of kolanut in mice. The results showed that there were no deaths caused by graded doses of the extract even at very high doses.

Effect of normal saline on blood glucose, blood flow and Hindlimb Glucose Uptake (HGU) at rest and during hindlimb muscle contraction

Normal Saline has no significant effect on arterial and venous blood glucose, (A-V) blood glucose, blood flow and hindlimb glucose uptake by the dog. The resting arterial and venous blood glucose levels were $99.3 \pm 1.4 \mathrm{mg} / \mathrm{dl}$ and $95.2 \pm 1.5$ $\mathrm{mg} / \mathrm{dl}$ respectively. The resting (A-V) glucose was $4.2 \pm 0.2 \mathrm{mg} / \mathrm{dl}$ and the resting blood flow to the skeletal muscle was $8.3 \pm 0.2 \mathrm{ml} / \mathrm{min}$. At rest, the Hindlimb Glucose Uptake (HGU) in the dogs was $34.8 \pm 0.1 \mathrm{mg} / \mathrm{min}$.

Contraction of hindlimb muscle caused insignificant increases in both arterial and venous glucose levels from $99.3 \pm 1.4 \mathrm{mg} / \mathrm{dl}$, and $95.2 \pm 1.5 \mathrm{mg} / \mathrm{dl}$ to $120 \pm 6.6 \mathrm{mg} / \mathrm{dl}$ and $98.4 \pm 3.3 \mathrm{mg} / \mathrm{dl}$ at twenty and twenty-five minutes respectively (Table 2). Figure 1a shows the effect of hindlimb contraction on arterio-venous glucose difference during hindlimb muscle contraction. There was a steady rise in $(\mathrm{A}-\mathrm{V})$ glucose, from $4.2 \pm 0.2 \mathrm{mg} / \mathrm{dl}$ to $24 \pm 2.7 \mathrm{mg} / \mathrm{dl}$ which reached its peak twenty minutes into the contraction period and thereafter gradually returns towards the basal level. The blood flow to the hindlimb also significantly increased from $8.3 \pm 0.2 \mathrm{ml} / \mathrm{min}$ to $14.5 \pm 0.6 \mathrm{ml} / \mathrm{min}(\mathrm{p}<0.01)$ and was sustained throughout the contraction and post-contraction observation periods (Figure 1b). Glucose uptake increased steadily from $34.8 \pm$ $0.1 \mathrm{mg} / \mathrm{min}$ to $180.7 \pm 3.3 \mathrm{mg} / \mathrm{min}$ in the first $20 \mathrm{~min}$, reaching its peak, and thereafter started to decrease. (Figure 1c). It is to be noted, that even in the post-contraction observation period, $(\mathrm{A}-\mathrm{V})$ glucose and glucose uptake did not return to the basal level.

Effect of caffeine on blood glucose, blood flow and Hindlimb Glucose Uptake (HGU) at rest in dogs

The effects of different doses (3, 6, and $9 \mathrm{mg} / \mathrm{kg}$ ) of caffeine on blood glucose are shown in table 3. Caffeine at $6 \mathrm{mg} / \mathrm{kg}$ caused significant increases in arterial blood glucose from
$99.2 \pm 0.7 \mathrm{mg} / \mathrm{dl}$ to $160.2 \pm 1.2 \mathrm{mg} / \mathrm{dl}$ at fifteen minutes post-injection. The increase in blood glucose was immediate and sustained throughout the 90min post-injection observation period. Caffeine at $6 \mathrm{mg} / \mathrm{kg}$ also produced significant increase in venous blood glucose from $94.9 \pm 1.5 \mathrm{mg} / \mathrm{dl}$ to $130.6 \pm 2.3 \mathrm{mg} / \mathrm{dl}$ which was sustained. The venous blood glucose levels are however lower than the arterial glucose levels throughout the post-injection observation period. $3 \mathrm{mg} / \mathrm{kg}$ of caffeine did not produce any significant effect on both the arterial and venous blood glucose levels. At a higher dose of $9 \mathrm{mg} / \mathrm{kg}$, caffeine produced significant reductions in both arterial and venous blood glucose levels from $99.3 \pm 1.2 \mathrm{mg} / \mathrm{dl}$ and $95.2 \pm 1.5 \mathrm{mg} / \mathrm{dl}$ to $88.0 \pm 5.3 \mathrm{mg} / \mathrm{dl}$ and $74.6 \pm 6.1 \mathrm{mg} / \mathrm{dl}$ respectively. The different doses of caffeine produced significant increases in the arterio-venous glucose difference in the hindlimb (figure 2a). While both $3 \mathrm{mg} / \mathrm{kg}$ and $9 \mathrm{mg} / \mathrm{kg}$ caffeine caused slight but significant increases in glucose extraction by the hindlimb, $6 \mathrm{mg} / \mathrm{kg}$ produced a more significant effect. The effect of $6 \mathrm{mg} / \mathrm{kg}$ of caffeine on glucose extraction by the hindlimb was immediate and sustained throughout the post-injection observation period. While $3 \mathrm{mg} / \mathrm{kg}$ and $9 \mathrm{mg} / \mathrm{kg}$ caffeine increased $(\mathrm{A}-\mathrm{V})$ glucose from $4.2 \pm 0.2 \mathrm{mg} / \mathrm{dl}$ to $19.6 \pm 2.4 \mathrm{mg} / \mathrm{dl}$ and $21.6 \pm 5.4 \mathrm{mg} / \mathrm{dl}$ respectively $(\mathrm{P}<0.05), 6 \mathrm{mg} / \mathrm{kg}$ caffeine produced maximum $(\mathrm{A}-\mathrm{V})$ glucose of $29.6 \pm 8.6 \mathrm{mg} / \mathrm{dl}(\mathrm{P}<0.01)$. Figure $2 \mathrm{~b}$ shows that caffeine significantly decreased blood flow to the hindlimb. The three doses of caffeine decreased blood flow also in a dose-dependent manner. The effects of caffeine on the hindlimb glucose uptake in the resting state are shown in figure $2 c$. Both $3 \mathrm{mg} / \mathrm{kg}$ and $6 \mathrm{mg} / \mathrm{kg}$ of caffeine produced significant increases in the glucose uptake from $35.6 \pm 1.2 \mathrm{mg} / \mathrm{min}$ to $79 \pm 1.3 \mathrm{mg} / \mathrm{min}$ and $75 \pm 3.2 \mathrm{mg} / \mathrm{min}$ respectively $(p<0.01)$. While, $9 \mathrm{mg} / \mathrm{kg}$ of caffeine did not produce any significant effect on the hindlimb glucose uptake. Comparing the $3 \mathrm{mg} / \mathrm{kg}$ and $6 \mathrm{mg} / \mathrm{kg}$ of caffeine, the $3 \mathrm{mg} / \mathrm{kg}$ caffeine produced a more significant $(\mathrm{P}<0.001)$ increase in the hindlimb glucose uptake. The increases in hindlimb glucose uptake in response to $3 \mathrm{mg} / \mathrm{kg}$ and $6 \mathrm{mg} / \mathrm{kg}$ of caffeine were immediate and sustained throughout the post-injection observation period. 
Caffeine and kolanut extract on canine hindlimb glucose uptake

Table 2: Effect of intravenous injection of saline $(0.1 \mathrm{ml} / \mathrm{kg})$ on arterial and venous blood glucose levels $(\mathrm{mg} / \mathrm{dl})$ at rest and during hindlimb contraction in dogs. Values are expressed as Mean \pm SEM. $(n=5)$

\begin{tabular}{|c|c|c|c|c|c|c|c|c|c|c|c|c|}
\hline Treatment & $\begin{array}{l}\text { Time } \\
(\mathrm{min})\end{array}$ & 0 & 5 & 10 & 15 & 20 & 25 & 30 & 45 & 60 & 75 & 90 \\
\hline \multirow{4}{*}{$\begin{array}{l}\text { Normal } \\
\text { Saline } \\
\text { (Rest) }\end{array}$} & & 100 & 97.4 & 98 & 98.2 & 97.6 & 98.4 & 98.2 & 97.6 & 97.8 & 97.6 & 98.2 \\
\hline & Arterial & \pm 1.4 & \pm 0.9 & \pm 0.8 & \pm 1.9 & \pm 1.2 & \pm 1.0 & \pm 1.4 & \pm 0.9 & \pm 0.8 & \pm 1.0 & \pm 0.4 \\
\hline & & 95 & 93.2 & 92 & 94 & 93.2 & 93.4 & 92.2 & 93.4 & 92.2 & 93.6 & 92.2 \\
\hline & Venous & \pm 1.5 & \pm 1.7 & \pm 1.1 & \pm 1.2 & \pm 1.5 & \pm 1.4 & \pm 1.2 & \pm 1.6 & \pm 1.4 & \pm 1.6 & \pm 1.7 \\
\hline \multirow{2}{*}{$\begin{array}{c}\text { Normal } \\
\text { saline } \\
\text { hindlimb } \\
\text { contraction) }\end{array}$} & Arterial & $\begin{array}{c}99 \\
\pm 1.4\end{array}$ & $\begin{array}{r}109 \\
\pm 5.4\end{array}$ & $\begin{array}{r}115 \\
\pm 5.7\end{array}$ & $\begin{array}{r}118 \\
\pm 6.5\end{array}$ & $\begin{array}{r}120 \\
\pm 6.6\end{array}$ & $\begin{array}{r}116 \\
\pm 6.1\end{array}$ & $\begin{array}{r}117 \\
\pm 7.1\end{array}$ & $\begin{array}{r}114 \\
\pm 5.6\end{array}$ & $\begin{array}{r}115 \\
\pm 4.2\end{array}$ & $\begin{array}{r}116 \\
\pm 5.5\end{array}$ & $\begin{array}{r}115 \\
\pm 5.8\end{array}$ \\
\hline & Venous & $\begin{array}{c}95 \\
\pm 6.0\end{array}$ & $\begin{array}{r}94.2 \\
\pm 5.2\end{array}$ & $\begin{array}{c}94 \\
\pm 6.2\end{array}$ & $\begin{array}{r}95.6 \\
\pm 2.1\end{array}$ & $\begin{array}{l}97.6 \\
\pm 2.1\end{array}$ & $\begin{array}{r}98.4 \\
\pm 3.3\end{array}$ & $\begin{array}{r}92.2 \\
\pm 4.2\end{array}$ & $\begin{array}{r}93.6 \\
\pm 4.7\end{array}$ & $\begin{array}{r}93.4 \\
\pm 5.1\end{array}$ & $\begin{array}{c}93 \\
\pm 5.6\end{array}$ & $\begin{array}{c}93 \\
\pm 5.6\end{array}$ \\
\hline
\end{tabular}

Table 3: Effects of intravenous injection caffeine $(3,6,9 \mathrm{mg} / \mathrm{kg}$ ) on arterial and venous blood glucose levels ( $\mathrm{mg} / \mathrm{dl})$ in dogs Values are expressed as mean \pm SEM. $(n=5)(* P<0.05 ; * * P<0.01)$

\begin{tabular}{|c|c|c|c|c|c|c|c|c|c|c|c|c|}
\hline 'reatment & $(\min )$ & 0 & 5 & 10 & 15 & 20 & 25 & 30 & 45 & 60 & 75 & 90 \\
\hline & Arterial & $\begin{array}{c}99.4 \\
\pm 0.7\end{array}$ & $\begin{array}{l}03.8 \\
=3.2\end{array}$ & $\begin{array}{l}96.2 \\
\pm 0.8\end{array}$ & $\begin{array}{c}97 \\
\pm 2.5\end{array}$ & $\begin{array}{l}97.4 \\
\pm 2.0\end{array}$ & $\begin{array}{c}104 \\
\pm 3.5\end{array}$ & $\begin{array}{c}101.4 \\
\pm 4.8\end{array}$ & $\begin{array}{l}02 \\
4.0\end{array}$ & $\begin{array}{l}102.2 \\
\pm 7.8\end{array}$ & $\begin{array}{l}104.4 \\
上 6.4\end{array}$ & $\begin{array}{c}107.2 \\
\pm 4.1\end{array}$ \\
\hline $\begin{array}{l}\text { Caffeine } \\
3 \mathrm{mg} / \mathrm{kg})\end{array}$ & Venous & $\begin{array}{c}95.1 \\
\pm 1.5 \\
\end{array}$ & $\begin{array}{c}86 \\
: 2.6 \\
\end{array}$ & $\begin{array}{r}85.4 \\
\pm 2.6 \\
\end{array}$ & $\begin{array}{r}85.6 \\
\pm 1.7 \\
\end{array}$ & $\begin{array}{l}82.2 \\
\pm 4.7 \\
\end{array}$ & $\begin{array}{r}84.4 \\
\pm 3.2 \\
\end{array}$ & $\begin{array}{r}82.2 \\
\pm 4.3 \\
\end{array}$ & $\begin{array}{l}82 \\
: 1.1 \\
\end{array}$ & $\begin{array}{r}82.6 \\
\pm 5.2 \\
\end{array}$ & $\begin{array}{l}35.4 \\
⺊ 2.9 \\
\end{array}$ & $\begin{array}{l}90.6 \\
\pm 2.0 \\
\end{array}$ \\
\hline $\begin{array}{l}\text { Caffeine } \\
6 \mathrm{mg} / \mathrm{kg})\end{array}$ & $\begin{array}{l}\text { Arterial } \\
\text { Venous }\end{array}$ & $\begin{array}{c}99.2 \\
\pm 1.4 \\
94.9 \\
\pm 1.5\end{array}$ & $\begin{array}{l}56.8 \\
.9 * * \\
40.4 \\
i .3 * *\end{array}$ & $\begin{array}{l}160.2 \\
=1.2^{* *} \\
133.8 \\
=3.7^{* *}\end{array}$ & $\begin{array}{c}59.8 \\
1.9 * * \\
37.6 \\
2.3 * *\end{array}$ & $\begin{array}{l}157.8 \\
=1.6 * * \\
133 \\
=3.9 * *\end{array}$ & $\begin{array}{l}159.4 \\
: 2.4 * * \\
129.6 \\
: 3.0 * *\end{array}$ & $\begin{array}{c}154.4 \\
\pm 3.5 * * \\
132.6 \\
\pm 3.4 * *\end{array}$ & $\begin{array}{l}51.8 \\
.8 * * \\
28.4 \\
7.5^{*}\end{array}$ & $\begin{array}{c}144.2 \\
\pm 1.2 * * \\
127.6 \\
\pm 4.5 *\end{array}$ & $\begin{array}{l}46.4 \\
3.5^{* *} \\
15.2 \\
3.6^{*}\end{array}$ & $\begin{array}{c}137 \\
\pm 5.3 * \\
124 \\
\pm 1.3 * *\end{array}$ \\
\hline & 4rterial & $\begin{array}{l}99.3 \\
\pm 1.2\end{array}$ & $\begin{array}{l}13.4 \\
: 4.2\end{array}$ & $\begin{array}{l}92.2 \\
\pm 5.9\end{array}$ & $\begin{array}{l}89.6 \\
=4.9 *\end{array}$ & $\begin{array}{c}88 \\
\pm 5.3 *\end{array}$ & $\begin{array}{l}92.6 \\
\pm 3.7\end{array}$ & $\begin{array}{c}85.4 \\
\pm 5.3^{*}\end{array}$ & $\begin{array}{l}90 \\
: 3.0\end{array}$ & $\begin{array}{l}92.8 \\
\pm 5.1\end{array}$ & $\begin{array}{l}30.8 \\
\leq 6.0\end{array}$ & $\begin{array}{l}93.2 \\
\pm 5.2\end{array}$ \\
\hline $\begin{array}{l}\text { Caffeine } \\
9 m g / K g)\end{array}$ & Venous & $\begin{array}{l}95.2 \\
\pm 1.5\end{array}$ & $\begin{array}{c}83 \\
: 3.9\end{array}$ & $\begin{array}{r}77.6 \\
\pm 3.6\end{array}$ & $\begin{array}{c}77 \\
+5.2\end{array}$ & $\begin{array}{c}76.6 \\
\pm 4.3^{*}\end{array}$ & $\begin{array}{c}76 \\
+5.2 *\end{array}$ & $\begin{array}{r}74.6 \\
\pm 6.1\end{array}$ & $\begin{array}{l}8.4 \\
7.5^{*}\end{array}$ & $\begin{array}{c}74.6 \\
\pm 6.1 *\end{array}$ & $\begin{array}{l}73.4 \\
4.4 *\end{array}$ & $\begin{array}{c}72.8 \\
\pm 6.1 *\end{array}$ \\
\hline
\end{tabular}

Effect of caffeine on blood glucose (A-V) glucose and glucose uptake during hindlimb contraction in dogs

The effect $6 \mathrm{mg} / \mathrm{kg}$ of caffeine on blood glucose during hindlimb contraction is shown in table 4. Contraction of hindlimb did not affect caffeine influence on arterial blood glucose levels although a slight reduction in venous glucose levels was obtained. The effect of caffeine on the $(\mathrm{A}-\mathrm{V})$ glucose in a contracting hind limb is shown in figure $3 \mathrm{a}$. While caffeine increased glucose extraction from $4.2 \mathrm{mg} / \mathrm{dl}$ to $26.2 \mathrm{mg} / \mathrm{dl}$ at rest, it also increased $(\mathrm{A}-\mathrm{V})$ glucose from $4.2 \mathrm{mg} / \mathrm{dl}$ to $35.6 \mathrm{mg} / \mathrm{dl}$ during contraction of the hindlimb. That is, contraction of hindlimb potentiated the glucose extraction effect of caffeine by the hindlimb $(\mathrm{p}<0.01)$.

The effects caffeine on blood flow during hindlimb contraction is shown in figure $3 b$.
Although, caffeine caused significant reduction in blood flow at rest, it however, caused a slight but significant increase in the first $10 \mathrm{mins}$ and returned to basal level during the contraction of the hindlimb. It must also be added that the blood flow to the hindlimb was significantly higher during the contraction of the hindlimb than at rest throughout the postinjection observation period.

The effect of caffeine on hindlimb glucose uptake (HGU) during muscular contraction of the canine hindlimb is shown in figure $3 \mathrm{c}$. Caffeine at rest increased hindlimb glucose uptake (HGU) by about $272 \%$. It further increased $\mathrm{HGU}$ by about $411 \%$, during contraction of the hindlimb. That is, contraction of hindlimb potentiated the action of caffeine on the hindlimb glucose uptake in the dog. 
H. M. Salahdeen and A. R. A. Alada

Table 4: Effects of intravenous injection of caffeine $(6 \mathrm{mg} / \mathrm{kg})$ on arterial and venous blood glucose levels ( $\mathrm{mg} / \mathrm{dl})$ during rest and hindlimb contraction in dogs. Values are expressed as Mean \pm SEM. $(n=5)(* p<0.05 ; * * p<0.01)$

\begin{tabular}{|c|c|c|c|c|c|c|c|c|c|c|c|c|}
\hline Treatment & $(\min )$ & 0 & 5 & 10 & 15 & 20 & 25 & 30 & 45 & 60 & 75 & 90 \\
\hline $\begin{array}{l}\text { Contraction } \\
\text { of Hindlimb }\end{array}$ & $\begin{array}{l}\text { Arterial } \\
\text { Venous }\end{array}$ & $\begin{array}{c}99 \\
\pm 1.4 \\
95 \\
\pm 6.0 \\
\end{array}$ & $\begin{array}{c}109 \\
\pm 1.4 \\
94 \\
\pm 5.2 \\
\end{array}$ & $\begin{array}{c}115 \\
\pm 5.4 \\
94 \\
\pm 6.2 \\
\end{array}$ & $\begin{array}{c}118 \\
\pm 5.7 \\
96 \\
\pm 2.1 \\
\end{array}$ & $\begin{array}{c}120 \\
\pm 6.5 \\
98 \\
\pm 2.1 \\
\end{array}$ & $\begin{array}{c}116 \\
\pm 6.6 \\
98 \\
\pm 3.3 \\
\end{array}$ & $\begin{array}{c}117 \\
\pm 6.1 \\
92 \\
\pm 4.2 \\
\end{array}$ & $\begin{array}{c}114 \\
\pm 7.1 \\
94 \\
\pm 4.7 \\
\end{array}$ & $\begin{array}{c}115 \\
\pm 5.6 \\
93 \\
\pm 5.1 \\
\end{array}$ & $\begin{array}{c}116 \\
\pm 4.2 \\
93 \\
\pm 5.6 \\
\end{array}$ & $\begin{array}{c}115 \\
\pm 5.5 \\
93 \\
\pm 5.6 \\
\end{array}$ \\
\hline $\begin{array}{c}\text { Caffeine } \\
\text { Contraction }\end{array}$ & $\begin{array}{l}\text { Arterial } \\
\text { Venous }\end{array}$ & $\begin{array}{l}99.3 \\
\pm 1.2 \\
95.4 \\
\pm 4.9 \\
\end{array}$ & $\begin{array}{c}131 \\
\pm 3.7 \\
115 \\
\pm 5.4^{*} \\
\end{array}$ & $\begin{array}{c}154 \\
\pm 3.8^{*} \\
126 \\
\pm 4.0 \\
\end{array}$ & $\begin{array}{c}160 \\
\pm 3.7 * * \\
132 \\
\pm 4.3^{*} \\
\end{array}$ & $\begin{array}{c}156 \\
\pm 5.1 * * \\
123 \\
\pm 4.9 \\
\end{array}$ & $\begin{array}{c}151 \\
\pm 3.6^{* *} \\
121 \\
\pm 3.1 \\
\end{array}$ & $\begin{array}{c}156 \\
\pm 4.1 * \\
121 \\
\pm 2.1 \\
\end{array}$ & $\begin{array}{c}148 \\
\pm 3.4^{*} \\
120 \\
\pm 2.1 * \\
\end{array}$ & $\begin{array}{c}149 \\
\pm 2.1 * \\
126 \\
\pm 3.2 * \\
\end{array}$ & $\begin{array}{c}149 \\
\pm 2.1 * \\
120 \\
\pm 2.3 \\
\end{array}$ & $\begin{array}{c}148 \\
\pm 4.2 * \\
118 \\
\pm 2.2 * \\
\end{array}$ \\
\hline
\end{tabular}

Table 5: Effects of intravenous injection of ethanol extract of kolanut (EEK) $(2.5$ and $5 \mathrm{mg} / \mathrm{kg}$ ) on arterial and venous blood glucose levels $(\mathrm{mg} / \mathrm{dl})$ at rest in dogs. Values are expressed as Mean \pm SEM. $(n=5)\left({ }^{*} p<0.05 ; * * p<0.01\right)$

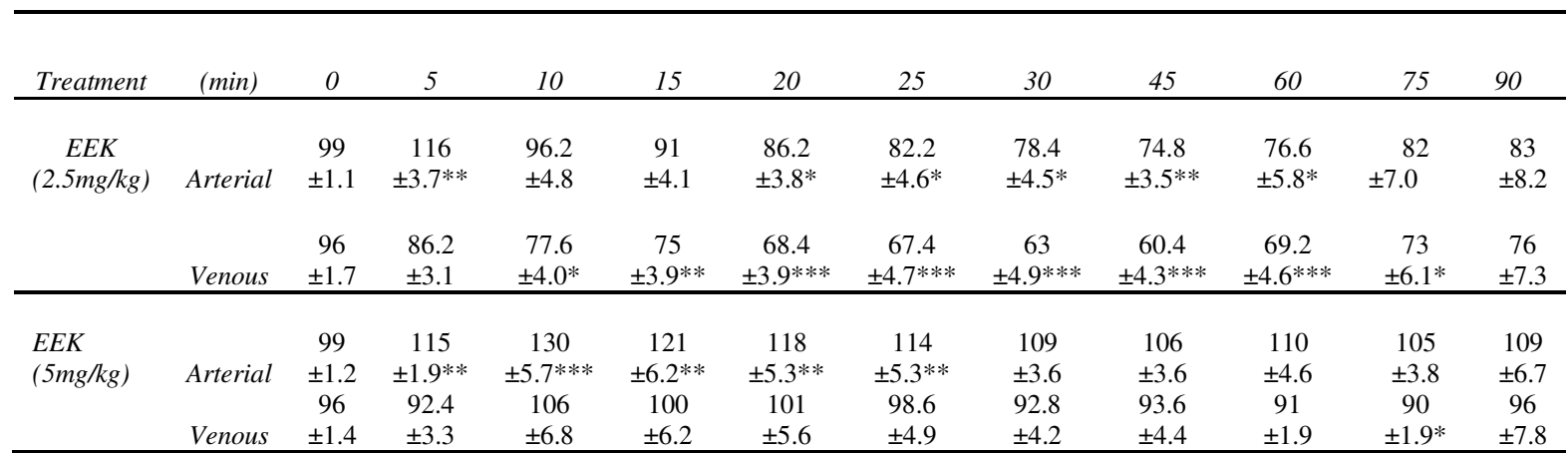

Table 6: Effects of intravenous injection of kolanut ethanolic extract (KEE) $(5 \mathrm{mg} / \mathrm{kg})$ on arterial and venous glucose ( $\mathrm{mg} / \mathrm{dl})$ during rest and during hindlimb muscles contraction in dogs. Values are expressed as Mean \pm SEM. $(n=5)(* \mathrm{p}<0.05$; $* * \mathrm{p}<0.01)$

\begin{tabular}{|c|c|c|c|c|c|c|c|c|c|c|c|c|}
\hline Time & $(\min )$ & 0 & 5 & 10 & 15 & 20 & 25 & 30 & 45 & 60 & 75 & 90 \\
\hline \multirow{4}{*}{$\begin{array}{l}\text { Contraction } \\
\text { of Hindlimb }\end{array}$} & \multirow{3}{*}{ Arterial } & 99 & 109 & 115 & 118 & 120 & 116 & 117 & $114 \pm 6$ & 115 & 116 & 115 \\
\hline & & \pm 1.4 & \pm 1.4 & \pm 1.4 & \pm 5.4 & \pm 5.7 & \pm 6.5 & \pm 6.6 & .1 & \pm 7.1 & \pm 5.6 & \pm 4.2 \\
\hline & & 95 & 94 & 94 & 96 & 98 & 98 & 92 & 94 & 93 & 93 & 93 \\
\hline & Venous & \pm 6.0 & \pm 5.2 & \pm 6.2 & \pm 2.1 & \pm 2.1 & \pm 3.3 & \pm 4.2 & \pm 4.7 & \pm 5.1 & \pm 5.6 & \pm 5.6 \\
\hline \multirow{4}{*}{$\begin{array}{l}\text { EEK } \\
\text { Contraction }\end{array}$} & \multirow{4}{*}{ Arterial } & & 115 & 130 & & 123 & 120 & 112 & & & & \\
\hline & & 99 & \pm 1.9 & $\pm 5.7 *$ & 123 & \pm 3.4 & $\pm 3.1 *$ & $\pm 3.0 *$ & 108 & 109 & 105 & 109 \\
\hline & & \pm 1.1 & $* *$ & $* *$ & $\pm 5 * * *$ & $* * *$ & $* *$ & $*$ & $\pm 3.2 *$ & $\pm 4.8^{*}$ & $\pm 4^{*}$ & $\pm 7^{*}$ \\
\hline & & $\begin{array}{c}94 \\
\pm 1.7\end{array}$ & $\begin{array}{r}104 \\
\pm 1.1\end{array}$ & $\begin{array}{c}110 \\
\pm 4.9 *\end{array}$ & $\begin{array}{c}107 \\
\pm 2.5^{*}\end{array}$ & $\begin{array}{c}105 \\
\pm 4.3 \\
*\end{array}$ & $\begin{array}{c}104 \\
\pm 2.8 *\end{array}$ & $\begin{array}{c}98 \\
\pm 1.0\end{array}$ & $\begin{array}{c}93 \\
\pm 2.2\end{array}$ & $\begin{array}{c}95 \\
\pm 2.3\end{array}$ & $\begin{array}{c}91 \\
\pm 1.1\end{array}$ & $\begin{array}{c}96 \\
\pm 7.3\end{array}$ \\
\hline
\end{tabular}

Effect of ethanolic extract kolanut (EEK) on blood glucose, (A-V) glucose and hindlimb glucose uptake (HGU) in the resting dog

The two doses of EEK $(2.5 \mathrm{mg} / \mathrm{kg}$ and $5 \mathrm{mg} / \mathrm{kg}$ ) produced slightly different pattern of responses (Table 5). While $2.5 \mathrm{mg} / \mathrm{kg}$ EEK caused an immediate but significant rise in both arterial and venous blood glucose levels from $99.3 \pm 1.4 \mathrm{mg} / \mathrm{dl}$ and $93.2 \pm 1.5 \mathrm{mg} / \mathrm{dl}$ to $116 \pm 6.8 \mathrm{mg} / \mathrm{dl}$ and $96 \pm 5.7 \mathrm{mg} / \mathrm{dl}$ followed by slight reduction to hypoglyceamic levels throughout the remaining post-injection observation period $(\mathrm{P}<0.05), 5 \mathrm{mg} / \mathrm{kg} \quad$ EEK caused immediate increases in arterial blood glucose, $99.3 \pm 1.4 \mathrm{mg} / \mathrm{dl}$ and $95.2 \pm 1.5 \mathrm{mg} / \mathrm{dl}$ to $106 \pm 6.8 \mathrm{mg} / \mathrm{dl}$ and $130 \pm 5.7 \mathrm{mg} / \mathrm{dl}$ which lasted for between $25 \mathrm{~min}$ to $30 \mathrm{~min}$ and thereafter returned to near basal levels during the remaining post-injection observation period $(\mathrm{P}<0.01)$. 


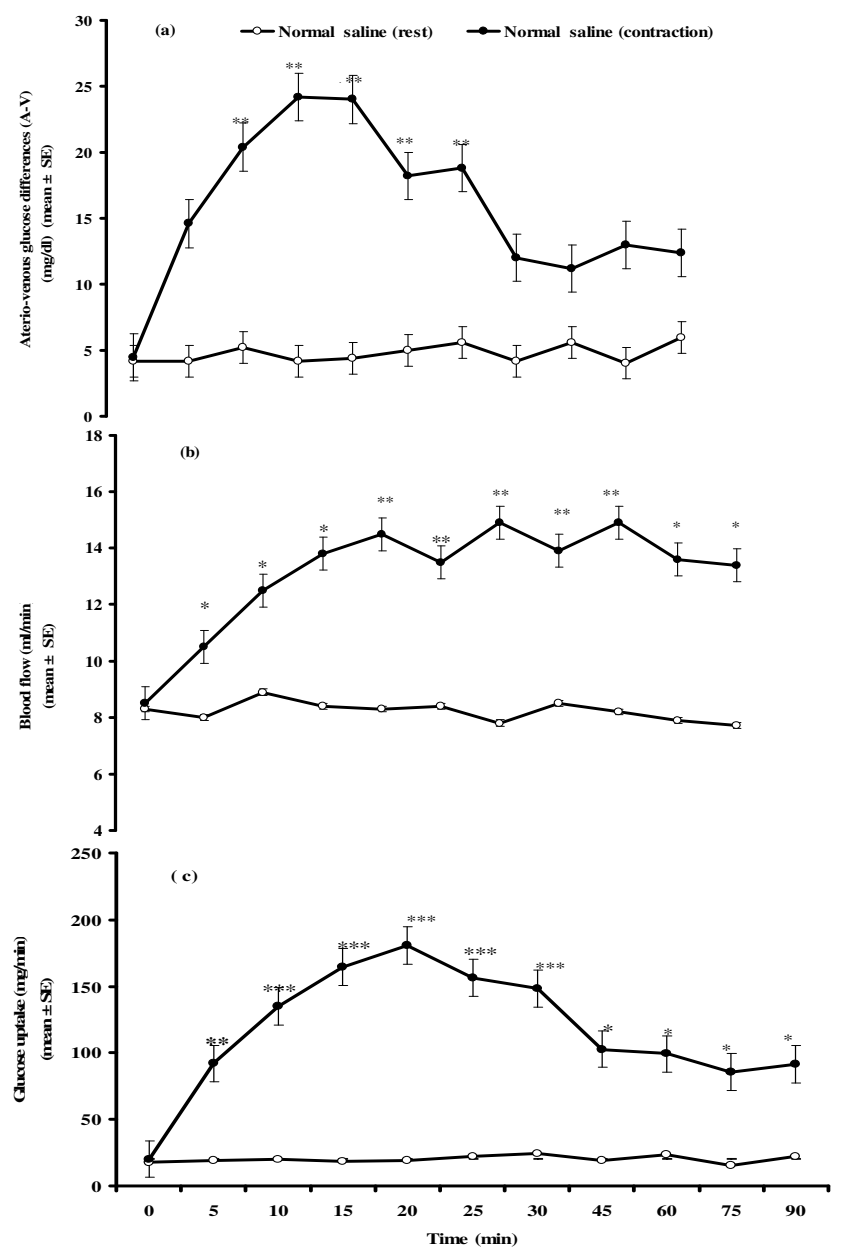

respectively. However, $5 \mathrm{mg} / \mathrm{kg}$ of EEK caused a greater decrease in blood flow than $2.5 \mathrm{mg} / \mathrm{kg}$ of EEK. The two doses $(2.5 \mathrm{mg} / \mathrm{kg}$ and $5 \mathrm{mg} / \mathrm{kg})$ produced different patterns of response in hindlimb glucose uptake (Figure 4c). While $2.5 \mathrm{mg} / \mathrm{kg}$ of EEK caused a sharp increase in $\mathrm{HGU}$, which lasted for 10min, and followed by return to basal level, the higher dose $(5 \mathrm{mg} / \mathrm{kg})$ produced a more sustained significant increase in HGU which lasted for about 30min. The lower dose of EEK, however, produced a higher HGU within the short period than the high dose of EEK. The maximum HGU in response to $2.5 \mathrm{mg} / \mathrm{kg}$ EEK is $402 \%$ and $511 \%$ in response to $5 \mathrm{mg} / \mathrm{kg}$ of EEK.

Effect of ethanolic extract kolanut (EEK) on blood glucose, $(A-V)$ and glucose uptake during hindlimb contraction in dogs

During contraction of the hindlimb, EEK produced a significant effect on the blood glucose levels. Administration of $5 \mathrm{mg} / \mathrm{kg}$ EEK during contraction of the hindlimb increased significantly both the arterial and venous glucose levels from $99.2 \pm 1.1 \mathrm{mg} / \mathrm{dl}$ and $93.8 \pm 1.7 \mathrm{mg} / \mathrm{dl}$ to $135 \pm 5.7 \mathrm{mg} / \mathrm{dl}$ and $110 \pm 4.9 \mathrm{mg} / \mathrm{dl}$ respectively. The arterial and venous glucose levels were sustainably higher throughout the post-injection observation period. The arterial blood glucose levels were also higher than the venous glucose levels (Table 6). The effect of EEK on (A-V) glucose during contraction of the hindlimb of the dog is shown in figure 5a. Following hindlimb contraction, (A-V) glucose increased from $4.2 \pm 0.2 \mathrm{mg} / \mathrm{dl}$ to $42.1 \pm 0.9 \mathrm{mg} / \mathrm{dl}$. The increase in

Fig. 1: Effect of intravenous injection of normal saline on (a) arterio-venous (b) blood flow (c) glucose uptake at rest and during hindlimb muscle contractions in dogs $(n=5) * P<0.05$; ** $P<0.01$; *** $P<0.01)$. Arrow shows point of drug injection.

Figure $4 \mathrm{a}$ shows that $2.5 \mathrm{mg} / \mathrm{kg}$ of EEK produced a significant increase in (A-V) glucose from $4.2 \pm 1.3 \mathrm{mg} / \mathrm{dl}$ to $16 \pm 2.6 \mathrm{mg} / \mathrm{dl}$ followed by a gradual returned to basal level $(\mathrm{P}<0.01)$, at $5 \mathrm{mg} / \mathrm{kg}$ EEK produced a more sustained increase in $(\mathrm{A}-\mathrm{V})$ glucose to $19 \pm 1.9 \mathrm{mg} / \mathrm{dl}$ which lasted for about 30min before returning to the basal levels $(\mathrm{P}<0.001)$.

Figure $4 \mathrm{~b}$ shows that the two doses of EEK produced significant decrease $(\mathrm{P}<0.05)$ in blood flow to the hindlimb, from resting value of $8.3 \pm 0.2 \mathrm{ml} / \mathrm{min}$ to $7.9 \pm 0.2 \mathrm{ml} / \mathrm{min}$ and $6.2 \pm 0.7 \mathrm{ml} / \mathrm{min}$ for both 2.5 and $5 \mathrm{mg} / \mathrm{kg}$ significantly higher than the $(\mathrm{A}-\mathrm{V})$ glucose of $23 \pm 2.6 \mathrm{mg} / \mathrm{dl}$ produced by EEK at rest. There was however, no significant difference in the effect of EEK during contraction of the hindlimb compared with the effect of contraction without EEK. The effect of EEK on blood flow is shown in figure $5 \mathrm{~b}$. During contraction of hindlimb, ethanolic extract of kolanut increased blood flow significantly to the hindlimb from $8.3 \pm 0.3 \mathrm{ml} / \mathrm{min}$ to $13 \pm 0.3 \mathrm{ml} / \mathrm{min}$. This result is in contrast to the reduction in blood flow caused by EEK in noncontracting state. The effect of EEK on HGU during contraction of the hindlimb is shown in figure $5 \mathrm{c}$. Contraction of the hindlimb increased HGU by $354 \%$. Administration of EEK resulted in a more significant increase in HGU. EEK caused $611 \%$ increase in $\mathrm{HGU}$ following contraction of the hindlimb. 


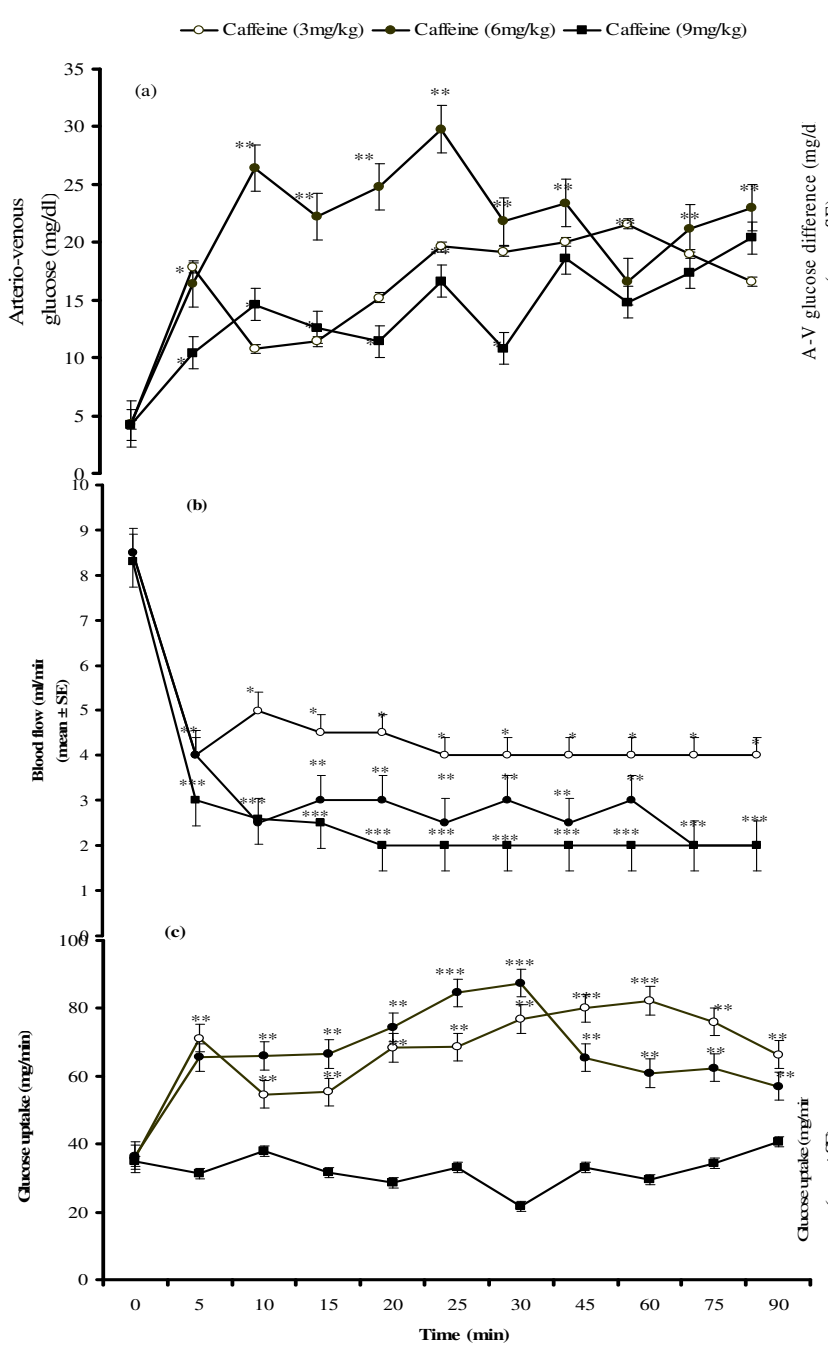

Fig.2: Effects of intravenous injection of caffeine (3, 6 and $9 \mathrm{mg} / \mathrm{kg}$ ) on (a) arterio-venous glucose difference (b) blood flow (c) glucose uptake at rest in dogs $(N=5) \quad(* p<0.05 ; \quad * * p<0.01$; $* * * p<0.001)$. Arrow shows point of drug injection.

\section{Discussion}

The observed increase in blood glucose level following administration of caffeine in dogs in this study agrees with the report of Pencek et al., (2004). It is also consistent with previous reports (Graham et al, 2000) whereby caffeine was reported to impair insulin mediated glucose disposal probably through release of adrenaline from adrenal medulla. Adrenaline is a well known hyperglycemic agent (Deibert and De Fronzo 1980; Alada and Oyebola 1997).

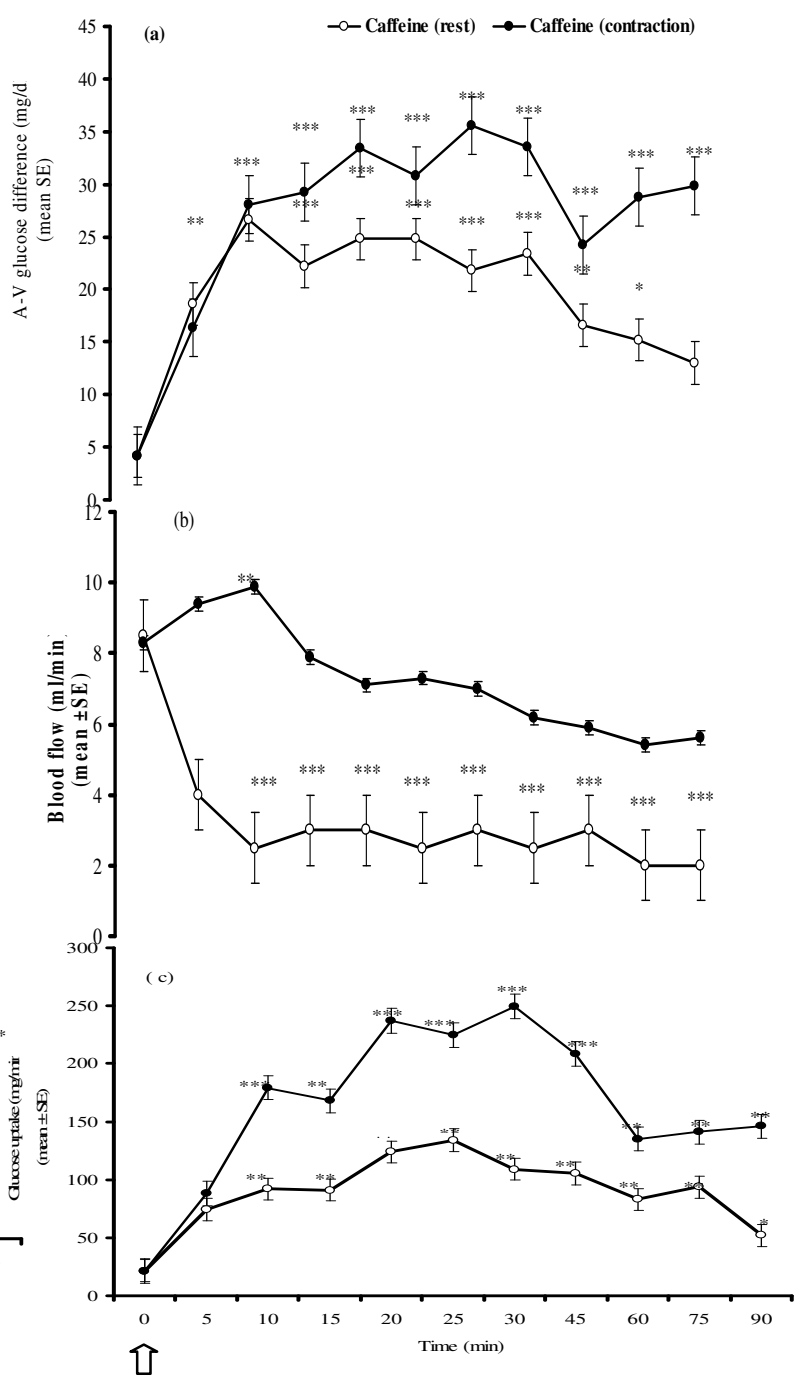

Fig.3: Effects of intravenous injection of caffeine $(6 \mathrm{mg} / \mathrm{kg})$ on (a) arterio-Venous glucose difference (b) blood flow (c) glucose uptake at rest and during hindlimb contraction in dogs. $(N=5) \quad(* p<0.05 ; \quad * * p<0.01 ; \quad * * * p<0.001)$. Arrow shows point of drug injection.

Adrenaline increases blood glucose level through the process of hepatic glycogenolysis and gluconeogenesis (Akiba et al, 2004). There are also several reports that showed that caffeine decreases insulin sensitivity (Greer et al, 2001; Robinson et al, 2004) through blockade of adenosine receptors (Thong and Graham 2002; Akiba et al, 2004). The observed increase in arterio-venous (A-V) glucose difference and hindlimb glucose uptake following 
Caffeine and kolanut extract on canine hindlimb glucose uptake

administration of caffeine is consistent with the reports of many workers in humans (Lee et al, 2005; Greer et al, 2001; Battram et al, 2005) and animals (Pencek et al, 2004). The increase in (AV) glucose observed in the present study showed that caffeine actually increased glucose
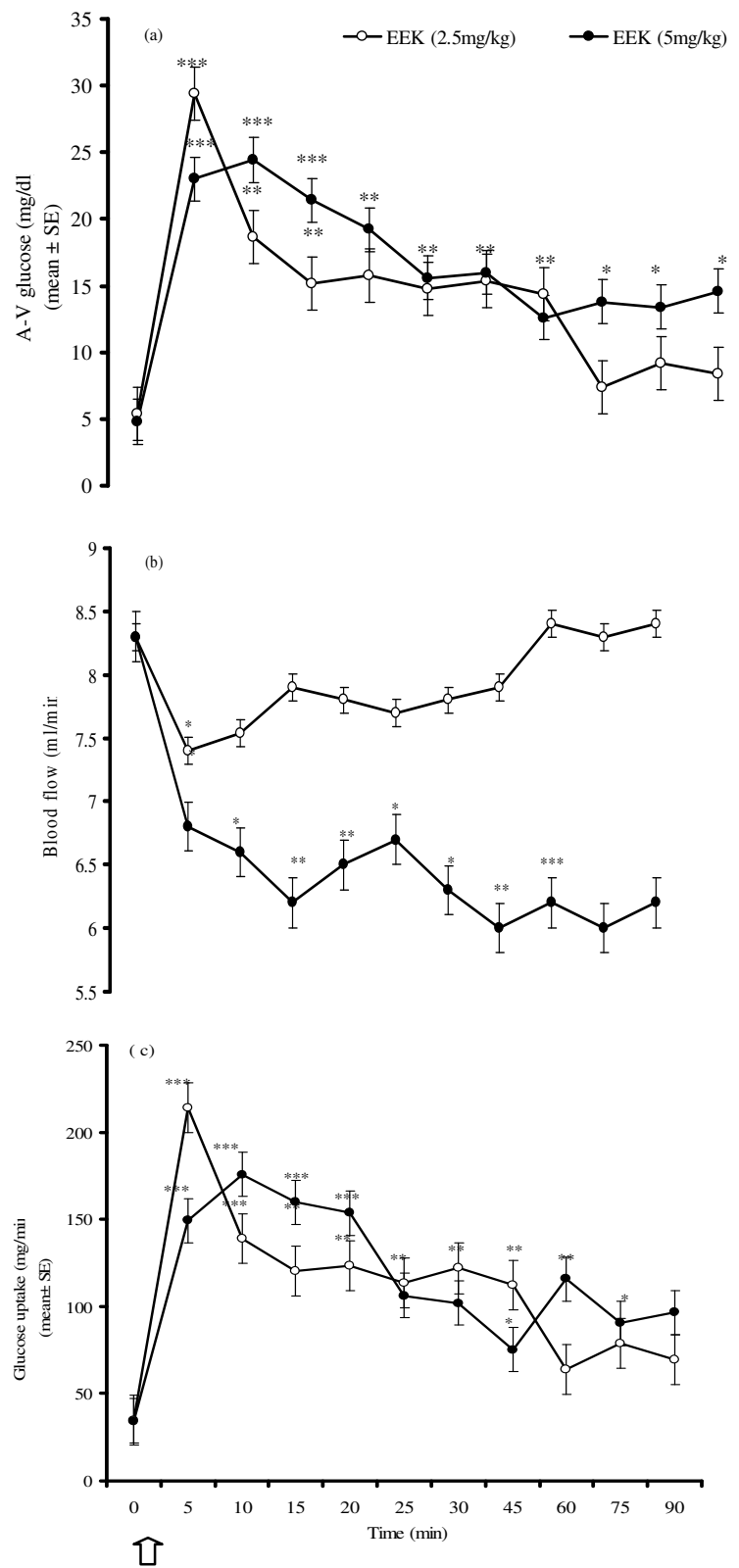

Fig.4: Effects of intravenous injection of ethanolic extract of kolanut (2.5 and $5 \mathrm{mg} / \mathrm{kg}$ ) on (a) arterio-venous glucose difference (b) blood flow (c) glucose uptake at rest in dogs $(N=5)$ $(* p<0.05 * * p<0.01, \quad * * * p<0.001)$. Arrow shows point of drug injection. extraction by the canine hindlimb despite the decrease in blood flow. The observed increase in glucose extraction by the hindlimb following administration of caffeine is probably a response to the increase in blood glucose levels, since both occur at about the same time.
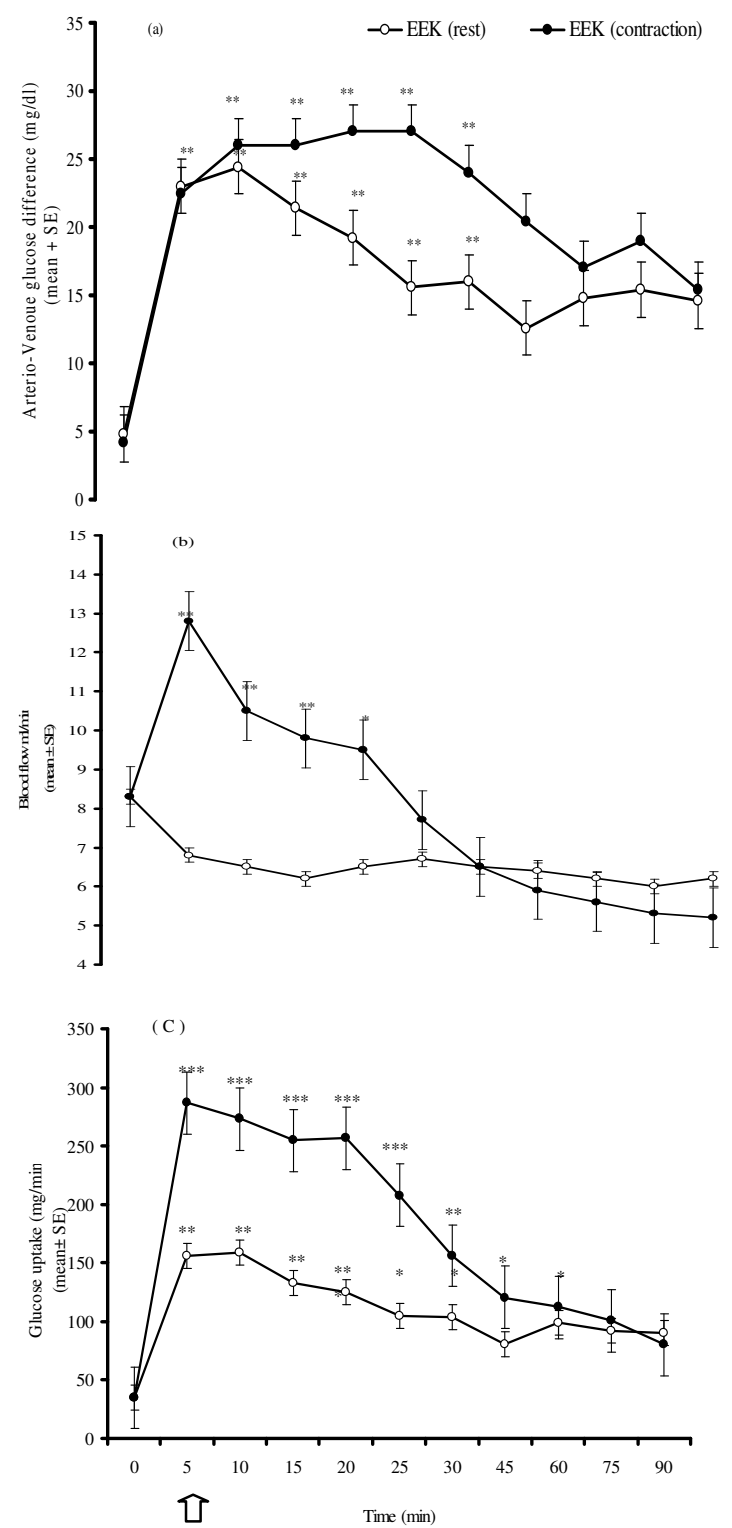

Fig. 5: Effect of intravenous injection of ethanolic extract of kolanut $(5 \mathrm{mg} / \mathrm{kg})$ on (a) arteriovenous glucose difference (b) blood flow (c) glucose uptake at rest and during hindlimb contraction in dogs. $(N=5) \quad(* p<0.05$; $* * p<0.01 ; * * * p<0.00)$. Arrow shows point of drug injection. 
Previous studies have shown that glucose transport across skeletal muscle cell membrane is enhanced during hyperglyceamia (Battram et al, 2005; Zierler, 1999) irrespective of its causes. There are also reports, which showed that caffeine-induced increases in skeletal muscle glucose uptake are through the release of calcium ions into the cytoplasm (Hardie and Sakamoto, 2006). Studies in which frog sartorius muscle was incubated with caffeine resulted in several fold increase in glucose transport due to release of calcium ion into the myoplasm (Hardie and Sakamoto, 2006; Rose and Richter 2005). In rat epitrochlearis muscle, raising intracellular calcium ions by treatment with caffeine in-vitro also increased glucose transport (Hardie and Sakamoto, 2006).

The significant reduction in hindlimb blood flow following caffeine administrations observed in this study is also consistent with the reported vasoconstriction effect of caffeine (Pincomb et al., 1985; 1991; Smits et al., 1986; Sung et al., 1994). The possible explanation for the vasoconstriction effect of caffeine is the blockade of vasodilatory actions of adenosine (Fredholm, 1995). Acute intake of caffeine has also been reported to increase vascular resistance (Smits et al., 1990). The reported increase in vascular resistance is consistence with the present report. The absence of any significant effect of caffeine on arterial blood glucose levels during contraction of hindlimb in this study seems to suggest that the hyperglyceamia produced by caffeine at rest has been removed during contraction of the hindlimb probably as a result of increased demand for glucose by the exercising muscles (Richter, 1996; Rose and Richter, 2005). Although few workers have reported a slight increase in blood glucose levels during exercise (Andersen and Saltin, 1985), most workers however, have reported no change in blood glucose during exercise (Rose and Richter, 2005). The greater increase in glucose extraction and hindlimb glucose uptake due to caffeine during contraction of the hindlimb muscles in this study is of great interest. It is well established that glucose uptake by skeletal muscle increases many folds during muscular exercise (Rose and Richter, 2005; Hardie and Sakamoto, 2006). Skeletal muscle is therefore a major sink for disposal of glucose in postprandial state. The higher increase in glucose extraction and glucose uptake due to caffeine during contraction of the hindlimb in the dog observed in this study seems to suggest that during hindlimb contraction, caffeine acts to argument the glucose uptake by the hindlimb. The mechanisms by which caffeine arguments glucose uptake by the canine hindlimb during exercise are not known. However, several mechanisms have been postulated to explain the effect of caffeine on glucose uptake during exercise.

Previous studies have shown that increasing glucose supply to the working muscle by raising glucose concentrations during contractions invitro (Richter et al, 1988; Petersen et al, 2003) or during exercise in-vivo (Richter, 1996) increases skeletal muscle glucose uptake during exercise even when insulin levels are prevented from rising (Rose and Richter, 2005; Akiba et al, 2004). Conversely, during prolonged exercise when insulin in blood decreases, glucose uptake decreases as well (Ahlborg et al, 1974). It is noteworthy, that within physiological range of glucose concentrations, the relationship between glucose concentration and insulin is also linear, indicating that changes in plasma glucose level translate in all proportionality to changes in glucose uptake by muscle (Rose and Richter, 2005), whereas the increase in muscle blood flow seems to match the glucose uptake demands of the contracting muscle (Anderson and Saltin, 1985) and does not pose any obvious limitation to glucose uptake in healthy individuals. The blood glucose concentration is an important limiting factor during muscular exercise (Rose and Richter, 2005).

Again, there are reports that caffeine induced glucose uptake through release of calcium ions into the myoplasm (Hardie and Sakamoto, 2006). An increase in calcium concentration in the myoplasm results in muscle contraction and alteration in the permeability of glucose. In this study, the significant reduction in blood flow to the hindlimb observed with EEK is similar to the observation on caffeine in the present study. The slight increase in blood glucose level produced by administration of EEk is of interest. After an extensive search of literature, there was no reported work on the effects of kolanut on blood glucose. Since the pattern and the magnitude of hyperglycemia induced by the ethanolic extract of kolanut are similar to that of caffeine, it will therefore be difficult not to conclude that the effect of ethanolic extract of kolanut on blood glucose is not due to caffeine. It is also true that caffeine is not the only active substance in EEK. Other active ingredients may also contribute to the various effects of kolanut. Further studies using other active ingredients of kolanut may shed 
Caffeine and kolanut extract on canine hindlimb glucose uptake

more light on this. There is however, no doubt that caffeine is a major contributor to the action of kolanut. The possible mechanism by which caffeine increases glucose level in this study had earlier been explained. The increase in hindlimb glucose extraction and glucose uptake observed in this study is consistent with the action of caffeine on other parameters measured in this study. Ethanolic extract of kolanut increased hindlimb glucose uptake by about $44 \%$ while caffeine $6 \mathrm{mg} / \mathrm{kg}$ produced about $700 \%$ increase. The difference in the magnitude of hindlimb glucose uptake by the two substances is probably due to the different concentrations of caffeine in circulation. Higher levels of caffeine in circulation have been reported to produce greater effects, for instance in blood pressure monitoring (Nurminen et al, 1999).

The potentiating effect of ethanolic extract of kolanut on hindlimb glucose uptake during contraction was also similar to the effect of caffeine under similar conditions. Contraction of the hindlimb muscle also tend to abolish the effect of ethanolic extract of Kolanut on blood flow, since in non-exercising animal ethanolic extract of kolanut produced an increase in vascular resistance and a decrease in blood flow. This is also similar to the effect of caffeine on blood flow and vascular resistance in the dog.

Generally, caffeine and ethanolic extract of kolanut seem to exhibit the same pattern of response with different magnitudes in all parameters measured in the present study. The difference in the effects of caffeine and EEK is only in the magnitude of the response and duration of the event. Since the concentration of caffeine in EEK used in this study was not determined, it will therefore be difficult to expect that the concentration of pure caffeine and caffeine in EEK will be the same. A pharmacodynamic study on the metabolism of kolanut may be necessary to throw more light on metabolic pathway of EEK. In similar studies using decaffeinated products of coffee, the significant role of caffeine in coffee, chocolate, cocoa and other food substances containing caffeine were highlighted (Nurminen et al, 1999). Most of the physiological effects of cola nitida are said to be due to caffeine. Although, the quantity of caffeine in the cola nitida was not determined in this study, the fact that ethanolic extract of kolanut increased mean arterial blood pressure (unpublished observation) supports the hypothesis that the pressor effect of kolanut is due to caffeine. Similar observation has been made with other food products such as coffee, cocoa, which contain caffeine (Khee and Jaworski, 1987). In actual fact, in some studies using decaffeinated coffee, there was no increase in blood pressure. An earlier worker (Somorin, 1973) found that cola nitida contains 0.16-gram caffeine per $100 \mathrm{~g}$ powder of kola nut. The concentration of caffeine used in this study is far less than the amount stated above. Since the effects of EEK on blood flow, and hindlimb glucose uptake are essentially similar to that of caffeine in this study, it will therefore be difficult not to conclude that the effects of EEK was being carried out by the presence of caffeine in it. Further studies whereby caffeine and other active substances in EEK will be isolated will throw more light on the mechanisms of action of EEK in the dog.

\section{References}

Ahlborg G, Felig P, Hagenfeldt L, Hendler R, and Wahren J. (1974). Substrate turnover during prolonged exercise in man. Splanchnic and leg metabolism of glucose, free fatty acids, and amino acids. $J$ Clin Invest , 53: 1080-1090.

Ajala M.O, Oladipo O.O, Fasanmade O and Adewole T.A. (2003). Laboratory assessment of three glucometers. Afri. J. Med. med. Sci. 32: 279-282.

Akiba T, Yaguchi K, Tsutsumi K, Nishioka T, Koyama I, Nomura M, Yokogawa K, Moritani S and Miyamoto K. (2004). Inhibitory mechanism of caffeine on insulinstimulated glucose uptake in adipose cells. Biochem Pharm; 68: 1929-1937.

Alada, A.R.A. and Oyebola D.D.O (1996). Evidence that the gastrointestinal tract is involved in glucose homeostasis. Afr Med med Sci. 25:243-249

Alada, A.R.A. and Oyebola D.O.O. (1997). The role of adrenergic receptors in the increased glucose uptake by canine gut. Afr. J. Med. med. Sci: 26: 75-78.

Andersen, P. and Saltin, B. (1985). Maximal perfusion of skeletal muscle in man. $J$ Physiol 366: 233-249.

Baron A.D, Wallace P, and Olefsky J.M. (1987). In vivo regulation of non-insulin mediated and insulin mediated glucose up take by epinephrine J. Clin Endo. Metab 64: 889 895.

Battram D.S, Bugaresti J, Gusba J and Graham T.E. (2007). Acute caffeine ingestion does not impair glucose tolerance in persons with tetraplegia. J. Appl. Physiol. 102: 374-381.

Battram D.S, Graham T.E, Richter E.A and Dela F. (2005). The effect of caffeine on glucose 
kinetics in humans - influence of adrenaline. J. Physiol; 569: 347-355.

Bessey P.Q, Brooks D.C, Black P.R, Aoki T.T and Wilmore D.W. (1983). Epinephrine acutely mediates skeletal muscle insulin resistance. Surgery; 94: 172-179.

Biaggioni I, Paul S, Puckett A, and Arzubiaga C. (1991). Caffeine and theophylline as adenosine receptor antagonists in humans. $J$ Pharm Exper Thera; 258: 588-593.

Christ G.H. Xu B. LaNoue K.F. Lang C.H. (1998). Tissue specific effects of in vivo adenosine receptor blockade on glucose uptake in Zucker rats. FASEB ; 12: 1301 1308.

Chukwu L.O., Odiete W.O., and Briggs, L.S. (2006). Basal metabolic regulatory responses and rhythmic activity of mammalian heart to aqueous kolanut extracts. Afr. J. Biotech. 5: 484-486.

Deibert D.C and De Fronzo R.A. (1980). Epinephrine - induced insulin resistance in man J Clin Invest. 65: 717 - 721.

Devreese K and Leroux-Roels G. (1993). Laboratory assessment of five glucose meters designed for self monitoring of blood glucose concentration. Eur. J. Clin. Biochem. 12:829837

Espinal J, Challiss R.A and Newsholme E.A. (1983). Effect of adenosine deaminase and an adenosine analogue on insulin sensitivity in soleus muscle of the rat. FASEB. 158: 103-106.

Fredholm B.B. (1995). Astra Award Lecture. Adenosine, adenosine receptors and the actions of caffeine. Pharm Toxicol. 76: 93101.

Graham T.E, Sathasivam P, Rowland M, Marko N, Greer F, and Battram D. (2001). Caffeine ingestion elevates plasma insulin response in humans during an oral glucose tolerance test. Can. J. Physiol. Pharmacol. 79: 559-565

Graham, T. E., Helge, J. W., and Maclean, D. A. (2000). Caffeine ingestion does not alter carbohydrate or fat metabolism in human skeletal muscle during exercise. J Physiol (Lond). 529: 837-847.

Greer F. Hudson R, Ross R and Graham T.E. (2001). Caffeine decreases glucose disposal during an euglycemic hyperinsulinemic clamp in sedentary males. Diabetes ; 50: $2349-2354$.

Hamada T, Hayashi T., Kimura T., Nakao K, and Moritani T. (2004). Electrical stimulation of human lower extremities enhances energy consumption, carbohydrate oxidation, and whole body glucose uptake. J. Appl. Physiol. 96: 911-916.

Han D.H. Hansen P.A. Nolte L. A. Holloszy J. O. (1998). Removal of adenosine decreases the responsiveness of muscle decrease transport to insulin and contractions Diabetes; 47: 1671 - 1675.

Hardie D.G. and Sakamoto, K. (2006). AMPK: A key sensor of fuel and energy status in skeletal muscle. Physiol. 21: 48-60.

Hellsten, Y., MacLean, D.A., RaÊdegran, G., Saltin, B. and Bangsbo, J. (1998). Adenosine concentrations in the interstitium of resting and contracting human skeletal muscle. Circulation. 98: 6-8.

Keijzers G.B, De Galan B.E, Jack G, and Smits P. (2002). Caffeine can decrease insulin sensitivity in humans. Diabetes care 25: 364 -369 .

Lee S, Hudson R, Kilpatrick K, Graham T.E and Ross R. (2005). Caffeine ingestion is associated with reductions in glucose uptake independent of obesity and type 2 diabetes before and after exercise training. Diabetes Care. 28: 566-572.

Leighton B, Lozeman F. Viachonikolis (1988). Effects of dipyridamole on the sensitivity of glucose transport, glycolysis and glycogen synthesis to insulin in muscles of the rat. Int. J Biochem. 20: 23 - 27.

Nurminen M.L., Niittynenl, Korpela R., Vapaatalo H., (1999). Coffee, caffeine and blood pressure: a critical review. Eur. J Clin Nutr. 53: 831-839.

Ogutuga, D.B.A. (1975). Chemical composition and potential commercial uses of kolanuts, Cola nitida vent Cachott and Endlisher) $G h$. J. Agri. Sci. 8: 121-125.

Pencek R.R, Battram D, Shearer J, James F.D, Lacy D.B. Jabbour K,Williams P.E, Graham T.E and Wasserman D.H (2004). Portal vein caffeine infusion enhances net hepatic glucose uptake during a glucose load in conscious dogs. J Nutr 134: 3042-3046.

Petersen HA, Fueger PT, Bracy DP, Wasserman DH, Halseth AE. (2003). Fiber type-specific determinants of Vmax for insulin-stimulated muscle glucose uptake in vivo. Am J.l of Physiol . 284; E541-E548.

Petrie H.J, Chown S.E, Belfie L.M, Duncan A.M, McLaren D.H, Conquer J.A and Graham T.E (2004). Caffeine ingestion increases the insulin response to an oralglucose-tolerance test in obese men before and after weight loss. Am. J Clin. Nutr. 80: 22-28. 
Caffeine and kolanut extract on canine hindlimb glucose uptake

Pincomb G.A, Lovallo W.R, Passey R.B, Whitesett T.L, Silverstein S.M and Wilson M.F. (1985). Effects of caffeine on vascular resistance, cardiac output and myocardial contractility in young men. Am. J Cardiol. 56: $119-122$.

Pincomb G. A, Wilson M. F. Sund B. H, Passey R. B and Lovallo W.R. (1991). Effect of caffeine on pressor regulation during rest and exercise in men at risk for hypertension. Am. Heart. J. 122: 1107 - 1115.

Richter E.A, Hansen S.A and Hansen B.F (1988). Mechanisms limiting glycogen storage in muscle during prolonged insulin stimulation. Am. J. Physiol 255: E621-E628.

Richter E.A. (1996). Glucose utilization. In: Handbook of Physiology. Exercise: Regulation and Integration of Multiple Systems. Bethesda, MD. Sect. 12, pp. 913951.

Robinson L.E, Savani S, Battram D.S, McLaren D.H, Sathasivam P and Graham T.E. (2004). Caffeine ingestion before an oral glucose tolerance test impairs blood glucose management in men with type 2 diabetes. $J$. Nutr 134: 2528-2533.

Rose A.J and Richter E. A. (2005). Skeletal muscle glucose uptake during exercise: How is it Regulated? Physiology 20: 260-270.

Smits P, Boekema P, De Abreu R, Thien T and van't Laar A (1987). Evidence for an antagonism between caffeine and adenosine in the human cardiovascular system. $J$. Cardiovasc. Pharmacol. 10: 136-143.
Smits P, Lenders J.W and Thien T. (1990). Caffeine and theophylline attenuate adenosine- induced vasodilation in humans. Clin. Pharmacol. Ther. 48: 410-418.

Smits P. Pieters G. Thien T. (1986). The role of epinephrine in the circulatory effects of coffee. Clin Pharmacol. Ther. 40: 431 - 437

Somorin O. (1973).Spectrometric determination of caffeine in Nigeria kolanuts. J .Food Sci. 381: 911-913.

Sung B.H, Whitsett T.L, Lovallo W.R, al'Absi M, Pincomb GA and Wilson MF (1994). Prolonged increases in blood pressure by a single oral dose of caffeine in mildly hypertensive men. Am. J. Hypertens 7: 755758.

Thong F.S, Derave W, Kiens B, Graham T.E, Urso B, Wojtaszewski JF, Hansen BF and Richter EA. (2002). Caffeine-induced impairment of insulin action but not insulin signaling in human skeletal muscle is reduced by exercise. Diabetes 51: 583-590.

Thong F.S, Graham T.E. (2002). Caffeine induced impairment of glucose tolerance of glucose is abolished. J Appl Physiol; 92: $2347-52$.

Vergauwen L, Hespel P, Richeter E.A. (1994). Adenosine receptors mediate synergistic. Stimulation of glucose uptake and transport by insulin and by contractive in rat skeletal muscle. J. Clin. Invest. 93: $974-981$.

Zierler K. (1999). Whole body glucose metabolism. Am. J. Physiol. E409-E426. 